\title{
Polycyclic aromatic hydrocarbon components contribute to the mitochondria-antiapoptotic effect of fine particulate matter on human bronchial epithelial cells via the aryl hydrocarbon receptor
}

Ioana Ferecatu', Marie-Caroline Borot ${ }^{1}$, Camille Bossard ${ }^{1}$, Melanie Leroux ${ }^{1}$, Nicole Boggetto ${ }^{2}$, Francelyne Marano ${ }^{1}$, Armelle Baeza-Squiban ${ }^{1}$, Karine Andreau ${ }^{1 *}$

\begin{abstract}
Background: Nowadays, effects of fine particulate matter $\left(\mathrm{PM}_{2.5}\right)$ are well-documented and related to oxidative stress and pro-inflammatory response. Nevertheless, epidemiological studies show that $\mathrm{PM}_{2.5}$ exposure is correlated with an increase of pulmonary cancers and the remodeling of the airway epithelium involving the regulation of cell death processes. Here, we investigated the components of Parisian $\mathrm{PM}_{2.5}$ involved in either the induction or the inhibition of cell death quantified by different parameters of apoptosis and delineated the mechanism underlying this effect.

Results: In this study, we showed that low levels of Parisian $\mathrm{PM}_{2.5}$ are not cytotoxic for three different cell lines and primary cultures of human bronchial epithelial cells. Conversely, a 4 hour-pretreatment with $\mathrm{PM}_{2.5}$ prevent mitochondria-driven apoptosis triggered by broad spectrum inducers (A23187, staurosporine and oligomycin) by reducing the mitochondrial transmembrane potential loss, the subsequent ROS production, phosphatidylserine externalization, plasma membrane permeabilization and typical morphological outcomes (cell size decrease, massive chromatin and nuclear condensation, formation of apoptotic bodies). The use of recombinant EGF and specific inhibitor led us to rule out the involvement of the classical EGFR signaling pathway as well as the proinflammatory cytokines secretion. Experiments performed with different compounds of $\mathrm{PM}_{2.5}$ suggest that endotoxins as well as carbon black do not participate to the antiapoptotic effect of $\mathrm{PM}_{2.5}$. Instead, the watersoluble fraction, washed particles and organic compounds such as polycyclic aromatic hydrocarbons (PAH) could mimic this antiapoptotic activity. Finally, the activation or silencing of the aryl hydrocarbon receptor (AhR) showed that it is involved into the molecular mechanism of the antiapoptotic effect of $\mathrm{PM}_{2.5}$ at the mitochondrial checkpoint of apoptosis.
\end{abstract}

Conclusions: The $\mathrm{PM}_{2.5}$-antiapoptotic effect in addition to the well-documented inflammatory response might explain the maintenance of a prolonged inflammation state induced after pollution exposure and might delay repair processes of injured tissues.

\footnotetext{
* Correspondence: karine.andreau@univ-paris-diderot.fr

'Université Paris Diderot-Paris 7. Unit of Functional and Adaptive Biology (BFA) CNRS EAC 4413, Laboratory of Molecular and Cellular Responses to Xenobiotics, Bâtiment Buffon, case courrier 7073, 5 rue Thomas Mann, 75013 Paris, France
} 


\section{Background}

Nowadays, air pollution is considered as a major inducer of harmful health effects, especially due to fine particulate matter $\left(\mathrm{PM}_{2.5}\right.$, atmospheric particles with an aerodynamic diameter equal or less than $2.5 \mu \mathrm{m})$. Urban $\mathrm{PM}_{2.5}$ is a mixture composed mainly of soots from fossil fuel combustion [1] together with several components adsorbed, including organic elements, biological species and metals [2]. In vitro short-term exposure to $\mathrm{PM}$ is associated with an inflammatory response as a consequence of cellular oxidative stress increase [3]. Fine PM are taken up by airway epithelial cells and alveolar macrophages $[4,5]$ leading to proinflammatory cytokine expression and release (i.e. GMCSF, IL-1 $\alpha$, IL-8, TNF $\alpha$, etc) [6,7] as well as the production of reactive oxygen species (ROS) [8]. Moreover, recent data demonstrate that short exposure of bronchial or nasal epithelial cells to urban $\mathrm{PM}_{2.5}$ provokes the secretion of EGFR ligands and Amphiregulin, which leads to GM-CSF secretion via an autocrine pathway [9].

Long-term effect of atmospheric particles remains underestimated. Nevertheless, epidemiological studies provide evidence of their deleterious impacts by increasing cardiopulmonary morbidity and mortality [10], asthma [11], bronchitis [12], exacerbation of chronic obstructive pulmonary disease (COPD, [13]). In addition, cancerous pathologies such as tracheal, bronchial and lung tumors are exacerbated [14]. In tissues, chronic exposure was associated with persistence of particles into the lungs leading to bronchioli wall thickening [15] and airway remodeling characterized by epithelial mucus-producing cells metaplasia, subepithelial fibrosis and airway smooth muscle hypertrophy/hyperplasia as observed in chronic asthma and COPD [16]. Thus, mechanisms involved in airway remodelling might be the excessive cell proliferation as well as the resistance to the apoptotic cell death.

Apoptosis is a programmed cell death defined by specific morphological alterations but with only slight ultrastructure modifications of cytoplasmic organelles and phosphatidylserine (PS) residue externalization [17]. It is noteworthy that mitochondrial alterations constitute the checkpoint of the apoptotic cell death. This is highlighted by the mitochondrial membrane permeabilization (MMP) which is measured by the decrease of mitochondrial transmembrane potential $(\Delta \Psi \mathrm{m})$, and by the subsequent superoxide anion production and Cytochrome $c$ release. The activation of caspases or other proteases triggers the proteolysis of specific substrates involved into the final appearance of morphological features of apoptosis. Most publications dealing with toxicity of airborne particles showed an induction of apoptosis associated with ROS generation, $\Delta \Psi \mathrm{m}$ drop, caspase-9 activation and DNA fragmentation [18]. In vitro experiments showed that PM-induced apoptosis was reported in normal human lung tissue or airway epithelial cells $[19,20]$.

The toxicity of ambient particles is mainly attributed to various adsorbed components. For instance, organic compounds are known to mimic the apoptotic effect of $\mathrm{PM}$ in various cell types through pathways which require the activation of the aryl hydrocarbon receptor (AhR) and the generation of ROS leading to DNA damage. Nevertheless, polycyclic aromatic hydrocarbon $(\mathrm{PAH})$ induced-apoptosis is mainly mediated via the mitochondria pathway in a p53-dependent manner [21]. Metals also affect human health, especially when these toxicants compete with essential elements and modify many cellular processes. Transition metals promote apoptosis through ROS generation, mitochondria dysfunction, activation of MAPK, p53 and caspases or down regulation of antiapoptotic proteins Bcl-2 [22]. Metals and the water-soluble fractions of PM are known to cause inflammation and cancer mostly due to DNA damage as a consequence of ROS generation by Fenton reaction. In addition, the exacerbation of asthma after inhalation of PM is mainly attributed to the biological compounds. Endotoxins induce proinflammatory cytokines production [23] and are able to provoke apoptosis-like cell death involving a scavenger receptor.

Most of PM pro-apoptotic data were obtained in vitro from acute exposure (with 80 to $100 \mu \mathrm{g} / \mathrm{cm}^{2}$ of particles) which usually corresponds to high pollution periods. The purpose of the present study was to investigate the effect of low doses of air particles $\left(\mathrm{PM}_{2.5}\right)$, on different bronchial epithelial cells (tumoral, immortalized and primary cells) regarding their induction or reduction of apoptosis. First, we found that Parisian $\mathrm{PM}_{2.5}$ are not cytotoxic, but have an antiapoptotic effect towards well-known cell death inducers, A23187, staurosporine and oligomycin. The reduced apoptosis observed after particle exposure is not related to the pro-inflammatory response and the EGF pathway. Moreover, water-soluble as well as organic components such as heavy PAH, are able to mimic the effects triggered by $\mathrm{PM}_{2.5}$, suggesting that such compounds are involved in the antiapoptotic effect. Finally, we identified the aryl hydrocarbon receptor as a molecular effector involved in the mechanism of the antiapoptotic effect of $\mathrm{PM}_{2.5}$ on human bronchial epithelial cells.

\section{Results \\ $\mathrm{PM}_{2.5}$ are not cyctotoxic in human bronchial epithelial cells}

First, we were interested in finding out whether particles from Parisian ambient air have cytotoxic effect on human bronchial cells. Thus, we exposed 16HBE human bronchial epithelial cells to increasing amount of $\mathrm{PM}_{2.5}$-AW from 1 to $50 \mu \mathrm{g} / \mathrm{cm}^{2}$. Several hallmarks of apoptotic cell 
death - recommended by the Nomenclature Committee on Cell Death [17] - were quantified by flow cytometry. Figure $1 \mathrm{~A}$ shows that $24 \mathrm{~h}$ exposure to $\mathrm{PM}_{2.5} \mathrm{AW}$ induced none of several hallmarks of apoptosis such as: $\Delta \Psi$ m drop (as quantified with DiOC6(3) low staining), oxidative potential (as quantified with the superoxide anion-reactive hydroethidine), phosphatidylserine exposure (driven by Annexin V-FITC positive staining) and plasma membrane permeabilization (allowing propidium iodide high staining). $\mathrm{H}_{2} \mathrm{O}_{2}$ is used here as positive control of apoptosis. Moreover, even when $16 \mathrm{HBE}$ cells were exposed for longer times to $\mathrm{PM}_{2.5}-\mathrm{AW}\left(1-50 \mu \mathrm{g} / \mathrm{cm}^{2}\right)$, no significative increase of apoptotic parameters was observed (Figure $1 \mathrm{~B}$ ) suggesting that $\mathrm{PM}_{2.5}$-AW do not have cytotoxic activity on human bronchial epithelial cells $16 \mathrm{HBE}$ exposed for 24 up to 72 hours. In order to determine if this lack of toxicity is specific to $16 \mathrm{HBE}$ cells, we extended our study to other human bronchial epithelial cells, such as NCI-H292 and BEAS-2B cell lines and to non-differentiated primary human bronchial epithelial cells (NHBE). Similarly to $16 \mathrm{HBE}$ cells, the dose effect study (1-50 $\left.\mu \mathrm{g} / \mathrm{cm}^{2}\right)$ of $\mathrm{PM}_{2.5}$-AW did not show any induction of apoptotic cell death, measured by $\Delta \Psi \mathrm{m}$ loss and PI high staining, with any of the three different cell types tested (Figure 1C). Conversely, cells tested herein were not resistant to apoptosis induction as demonstrated after $24 \mathrm{~h}$ incubation with hydrogen peroxide.

These results might be related to the batch of $\mathrm{PM}_{2.5}$ used, in particular timing and location of particle collection. To test this hypothesis, we used several batches of Parisian $\mathrm{PM}_{2.5}$ : Auteuil-Winter (AW), Auteuil-Summer (AS), Vitry-Winter (VW) or Vitry-Summer (VS) collected in the Paris area: (i) Porte d'Auteuil adjacent to a major highway and considered as a curbside station and (ii) a school playground at Vitry-sur-Seine in the suburb of Paris. When bronchial cells were exposed $24 \mathrm{~h}$ to these $\mathrm{PM}_{2.5}\left(10 \mu \mathrm{g} / \mathrm{cm}^{2}\right)$, we noticed only an increased granularity corresponding to particle uptake without any reduction in cell size (data not shown). Apoptotic cell death was then quantified by $\Delta \Psi \mathrm{m}$ loss and plasma membrane permeabilization, and none of these parameters was

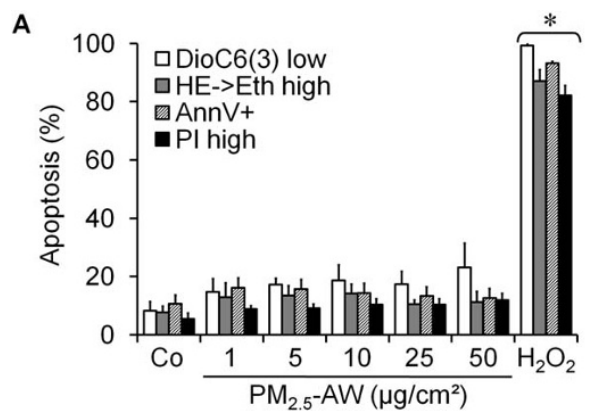

C

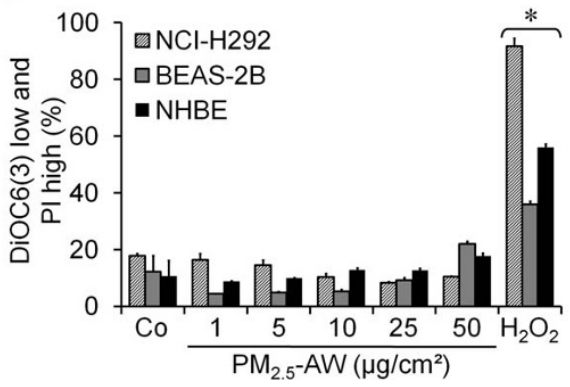

B

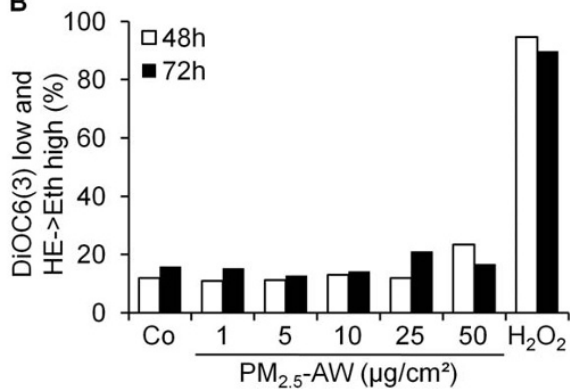

D

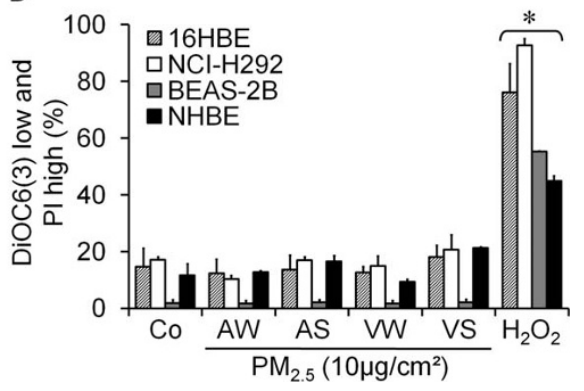

Figure 1 Effect of $\mathbf{P M}_{2.5}-\mathbf{A W}$ exposure on human bronchial epithelial cells. (A) Dose response of DiOC6(3) (to measure the mitochondrial $\triangle \Psi \mathrm{m}$ drop), hydroethidine (HE, ROS-sensitive dye), Annexin V-FITC (for phosphatidylserine exposure) and the propidium iodide (PI, as a plasma

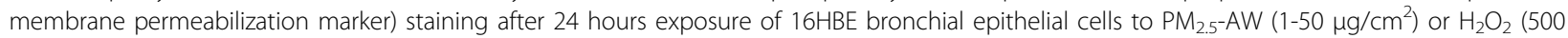
$\mu \mathrm{M})$. (B) Kinetic study of $\mathrm{PM}_{2.5}-\mathrm{AW}$ effect on apoptosis. $16 \mathrm{HBE}$ cells were exposed to $\mathrm{PM}_{2.5}-\mathrm{AW}$ (1 to $50 \mu \mathrm{g} / \mathrm{cm}^{2}$ ) or $\mathrm{H}_{2} \mathrm{O}_{2}$ (500 $\left.\mu \mathrm{M}\right)$ for $48 \mathrm{~h}$ or 72 $\mathrm{h}$ before flow cytometric analysis of cells presenting simultaneously a mitochondrial depolarization (DiOC6(3) low) and a superoxide anion generation (HE $\rightarrow$ Eth high). Results are representative of three independent experiments. (C) Subconfluent bronchial epithelial cell lines $\mathrm{NCl}$ H292, BEAS-2B and primary bronchial epithelial cells (NHBE) were exposed $24 \mathrm{~h}$ to $1-50 \mathrm{\mu g} / \mathrm{cm}^{2} \mathrm{PM}_{2.5}-\mathrm{AW}$, and $\mathrm{H}_{2} \mathrm{O}_{2}$ (1 mM) before flow cytometric analysis of cells presenting simultaneously a DiOC6(3) low and PI high staining. (D) Human bronchial epithelial cells 16HBE, NCl-H292, BEAS-2B or NHBE were exposed 24 hours to $10 \mu \mathrm{g} / \mathrm{cm}^{2}$ of different batches of $\mathrm{PM}_{2.5}$ (Auteuil-Winter (AW), Auteuil-Summer (AS), Vitry-Winter (VW) or Vitry-Summer (VS) corresponding to two locations of Paris: (i) a school playground at Vitry-sur-Seine in a suburb of Paris and (ii) Porte $\mathrm{d}^{\prime}$ Auteuil adjacent to a major highway). Then, cells were analyzed as previously described. Data are represented as mean \pm SD $\left({ }^{*}\right.$ treated vs. control, $p<0.05, \mathrm{n}=3$ ). 
significantly increased by exposure to the four different batches of $\mathrm{PM}_{2.5}$ (Figure 1D). Altogether, Parisian $\mathrm{PM}_{2.5}$ seem to have no cytotoxic effect in several human bronchial epithelial cells, including the primary NHBE cells.

\section{Parisian $\mathrm{PM}_{2.5}$ have an antiapoptotic effect}

The lack of cytotoxicity of $\mathrm{PM}_{2.5}$ on $16 \mathrm{HBE}$ does not mean that atmospheric particles do not modify the state of bronchial cells, for instance the capacity to die by apoptosis. Indeed, some components adsorbed on $\mathrm{PM}_{2.5}$ are well-known modulators of the apoptotic process. To determine whether $\mathrm{PM}_{2.5}$ were able to reduce cell death, $16 \mathrm{HBE}$ cells were exposed $24 \mathrm{~h}$ to A23187 ( $3 \mu \mathrm{M})$, a calcium ionophore known to induce apoptosis acting through endoplasmic reticulum and mitochondria stress in HeLa cells [24]. A transmission electron microscopy study of $16 \mathrm{HBE}$ cells exposed to A23187 showed typical morphological alterations of apoptosis such as reduction in cellular volume, nuclear chromatin condensation (pyknosis), organelle modifications, but with maintenance of the plasma membrane integrity (Figure 2A). In agreement with previous results, particle exposure alone did not alter $16 \mathrm{HBE}$ ultrastructure. However, when $\mathrm{PM}_{2.5}$ - AW were added $4 \mathrm{~h}$ prior to A23187, particles prevented apoptotic alterations and maintained nuclear and mitochondrial morphologies similar to the control condition. Moreover, A23187 alone provoked the reduction of cell size (66.2\% of control) and increased granularity $\left(149.2 \%\right.$ of control) but $\mathrm{PM}_{2.5}$-AW $\left(50 \mu \mathrm{g} / \mathrm{cm}^{2}\right)$ totally counteracted the cellular volume decrease (data not shown).

These results strongly suggest that $\mathrm{PM}_{2.5}$ might have an antiapoptotic effect. To test this, we used widespread cell death inducers directed against different organelles or effectors of apoptosis such as: three mitochondrial respiratory chain inhibitors (rotenone, antimycin and oligomycin), two calcium ionophores (ionomycin and A23187), a protein kinase inhibitor (STS), and an oxidative stress inducer (hydrogen peroxide, Figure $2 \mathrm{~B}$ and 2C). A 4 h pretreatment with $\mathrm{PM}_{2.5}$-AW allowed a significant reduction of apoptosis induced by the ATP synthase inhibitor oligomycin (33\% reduction of DiOC6 (3) low), the calcium ionophore A23187 (35\% reduction of DiOC6(3) low) and staurosporine (44\% reduction of DiOC6(3) low), but not by ionomycin, rotenone, antimycin $\mathrm{A}$ and $\mathrm{H}_{2} \mathrm{O}_{2}$. Furthermore, experiments performed in NCI-H292 and NHBE cells showed that $\mathrm{PM}_{2.5}-\mathrm{AW}$ also reduced apoptosis induced by A23187 or STS but not by $\mathrm{H}_{2} \mathrm{O}_{2}$ suggesting that the antiapoptotic effect of atmospheric particles could be a general feature of human bronchial epithelial cells (Figure 2C and 2D). Toxicological studies showed that $\mathrm{PM}_{2.5}$-AW significantly prevented mitochondrial and plasma membranes alterations of apoptosis at concentrations as high as $5 \mu \mathrm{M}$ of A23187
(Figure $3 \mathrm{~A}$ and 3B). Moreover, the antiapoptotic effect of $\mathrm{PM}_{2.5}$ - AW was partially efficient at $10 \mu \mathrm{g} / \mathrm{cm}^{2}$ and totally effective for concentrations beyond $25 \mu \mathrm{g} / \mathrm{cm}^{2}$ (Figure $3 \mathrm{C}$ and $3 \mathrm{D}$ ) suggesting that the antiapoptotic activity of $\mathrm{PM}_{2.5}$ is effective at the mitochondrial checkpoint.

Recently, we showed that nanoparticles are responsible for cytokines adsorption (such as GMC-SF and TNF $\alpha$ ) as well as other proteins like fetal calf serum or bovine serum albumin [25]. To investigate if the reduction in A23187-mediated apoptosis observed with $\mathrm{PM}_{2.5}$ pretreatment was not due to a possible adsorption of A23187 onto particles, we performed two different experiments. On one hand, inhibition of apoptosis was still maintained when cells were first exposed to $\mathrm{PM}_{2.5}$ followed by several washes before addition of the apoptotic inductor (Figure $4 \mathrm{a}$ and $4 \mathrm{~b}$ ). On the other hand, $\mathrm{PM}_{2.5}$ and the apoptotic inducer were incubated together without cells. After sedimentation, the supernatant containing the nonadsorbed inducer was added to $16 \mathrm{HBE}$ cells. This does not seem to reduce the apoptotic effect of A23187 (Figure 4c). Altogether, these two experiments show that the apoptotic resistance is not related to the adsorption onto $\mathrm{PM}_{2.5}$ but rather suggest a specific molecular mechanism occurring in bronchial epithelial cells.

\section{The antiapoptotic effect of $\mathrm{PM}_{2.5}$ is related to organic and water-soluble components}

Several studies on atmospheric particles underlined that cytotoxic effect of PM were linked to an oxidative stress and secretion of proinflammatory cytokines via the epidermal growth factor receptor (EGFR) ligands such as Amphiregulin (AR). Thus, we analyzed the secretion of GM-CSF and AR after performing a $4 \mathrm{~h}$ or a $24 \mathrm{~h} \mathrm{PM}_{2.5}$ exposure (Figure 5A). Results showed that AR and GMCSF secretion occur only after a $24 \mathrm{~h}$ exposure, which is in agreement with previous studies published on $\mathrm{PM}_{2.5^{-}}$ VW and $\mathrm{PM}_{2.5}$-AS $[9,26]$. Our results suggest that the antiapoptotic activity of $\mathrm{PM}_{2.5}$, which is an early event, is not related to the EGFR pathway and secretion of proinflammatory cytokines which is a late event. To confirm this, we used a recombinant EGF ligand (rEGF) or the inhibitor of EGF receptor (AG1478, Figure 5B) to show that none of the two compounds modifies the reduction of A23187-induced apoptosis.

In order to identify the components of $\mathrm{PM}_{2.5}$ involved in the process of the antiapoptotic effect described herein, we compared the capacity of the four different batches of Parisian $\mathrm{PM}_{2.5}$ to reduce apoptosis mediated by A23187. Surprisingly, solely $\mathrm{PM}_{2.5}$-VS were unable to reduce apoptosis (Figure 6A) suggesting that the antiapoptotic effect of $\mathrm{PM}_{2.5}$ might be associated with some compounds which are less present in $\mathrm{PM}_{2.5}$-VS batch 
A

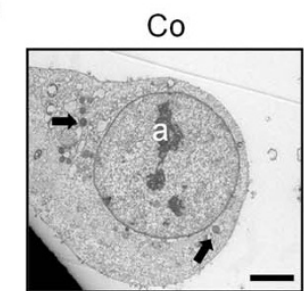

B

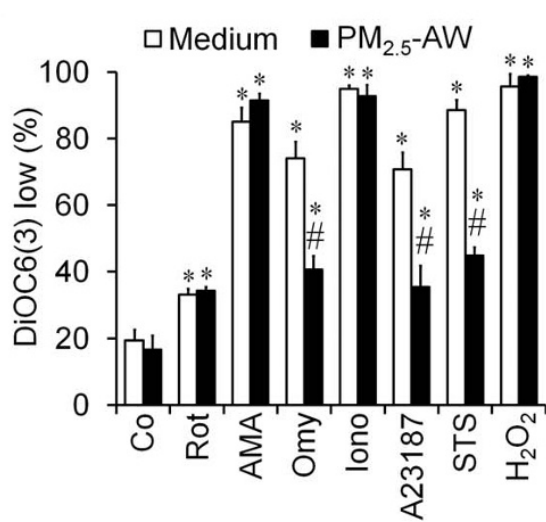

C

$\mathrm{PM}_{2.5}-\mathrm{AW}$

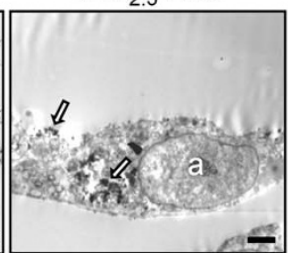

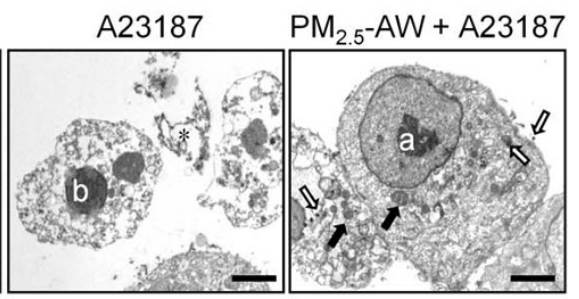

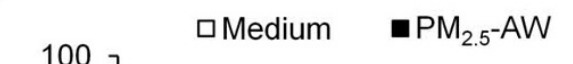

口Medium

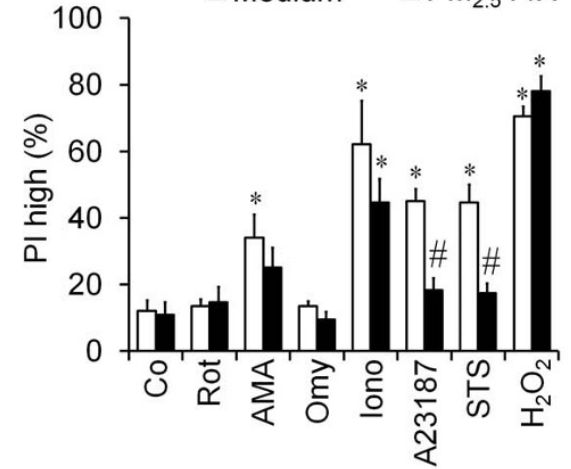

E NHBE

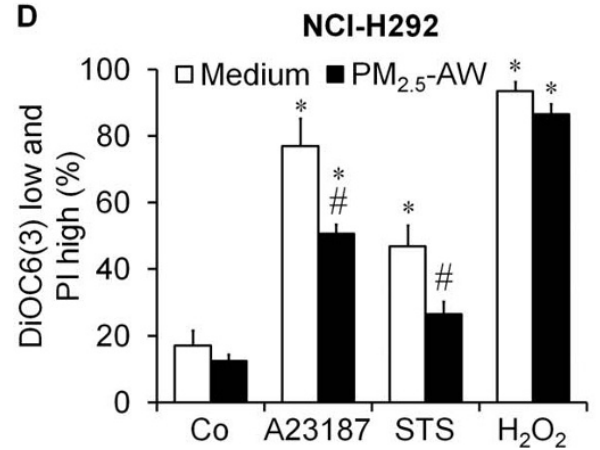

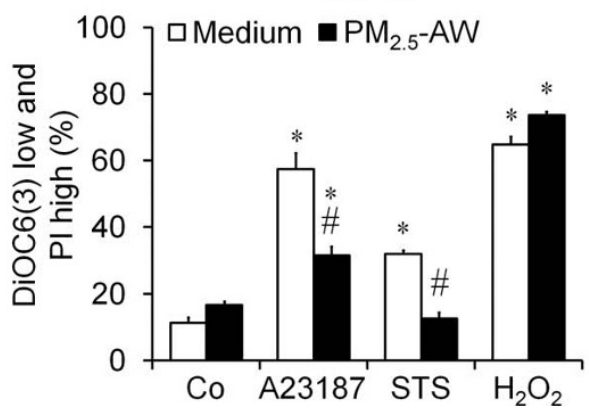

Figure 2 Parisian $\mathrm{PM}_{2.5}$ have an antiapoptotic effect against several death inducers. (A) Transmission electron microscopy of $16 \mathrm{HBE}$ cells treated $24 \mathrm{~h}$ with A23187 (3 $\mu \mathrm{M})$ in the absence or in the presence of a $4 \mathrm{~h}$ pretreatment with $10 \mu \mathrm{g} / \mathrm{cm}^{2} \mathrm{PM}_{2.5} \mathrm{AW}$. The micrographs illustrate that control or $\mathrm{PM}_{2.5}$-treated cells show normal nuclear chromatin condensation with the presence of some nucleoli (a) and normal ultrastructure of mitochondria (black arrow). PM's aggregates are localized near to the plasma membrane of cells exposed to particles or into the cytoplasm (white arrows). Treatment with A23187 alone triggered typical features of apoptotic cell death characterized by reduced cellular volume, massive chromatin condensation (b), formation of apoptotic bodies (black asterisk) and maintenance of the plasma membrane integrity. Note that $\mathrm{PM}_{2.5}$-AW pretreatment prevented A23187-induced morphological modifications and allowed $16 \mathrm{HBE}$ cells to retain nuclear or mitochondria morphologies similar to those of the control. Scale bar represent $5 \mu \mathrm{m}$. (B and C) After a $4 \mathrm{~h}$ pretreatment with $P M_{2.5}-\mathrm{AW}\left(10 \mu \mathrm{g} / \mathrm{cm}^{2}\right), 16 \mathrm{HBE}$ cells were exposed to different inducers of cell death for another $20 \mathrm{~h}$ such as mitochondrial respiratory chain inhibitors (rotenone (Rot, $5 \mu \mathrm{M})$, antimycin A (AMA, $25 \mu \mathrm{g} / \mathrm{ml}$ ) and oligomycin $(\mathrm{Omy}, 5 \mu \mathrm{M})$ ), calcium ionophores (ionomycin (lono, $0.5 \mu \mathrm{M}$ ) and A23187, $3 \mu \mathrm{M}$ ), protein kinases inhibitor (staurosporine STS, $1 \mu \mathrm{M}$ ) and oxidative stress activator $\left(\mathrm{H}_{2} \mathrm{O}_{2}, 500 \mu \mathrm{M}\right)$. Then, cells were quantified for DiOC6(3) low or PI high staining by flow cytometry. (D and E) The human bronchial epithelial NCl-H292 cell line and NHBE primary cells were assessed by flow cytometry in the presence or the absence of $\mathrm{PM}_{2.5}$-AW pretreatement $\left(10 \mu \mathrm{g} / \mathrm{cm}^{2}\right)$ and apoptosis inducers: A23187 (3 $\mu \mathrm{M})$, staurosporine (STS, $1 \mu \mathrm{M})$ and $\mathrm{H}_{2} \mathrm{O}_{2}(500 \mu \mathrm{M})$. Experiments were repeated three times, and means \pm S.D. are shown. Significance was calculated with respect to untreated controls $\left({ }^{*}, p<0.001\right)$ and with respect to non-pretreated cells with particles $(\#, p<0.001)$.

than in the others. In opposite, the lack of antiapoptotic effect might also be attributed to components more absorbed in $\mathrm{PM}_{2.5}$-VS than the others. Indeed, chemical analysis of all batches showed that $\mathrm{PM}_{2.5}$-VS contain more metals and less organic compounds (especially heavy $\mathrm{PAH}$ ) than $\mathrm{PM}_{2.5}-\mathrm{AW}$, AS and $\mathrm{VW}$ batches [2]. Thus, we tested $\mathrm{PM}_{2.5}-\mathrm{AW}$ organic extracts (Oex) and washed particles devoid of water-soluble components, $\mathrm{PM}_{2.5}-\mathrm{AW}$ aqueous extracts (Aex) and $95 \mathrm{~nm}$-carbon black particles (CB). Figure 6A shows that aqueous and organic extracts and, in a less extent washed particles, can mimic the antiapoptotic activity of whole $\mathrm{PM}_{2.5}$. In contrast, $\mathrm{CB}$ particles were unable to protect from apoptosis triggered by A23187. This suggests that water- 


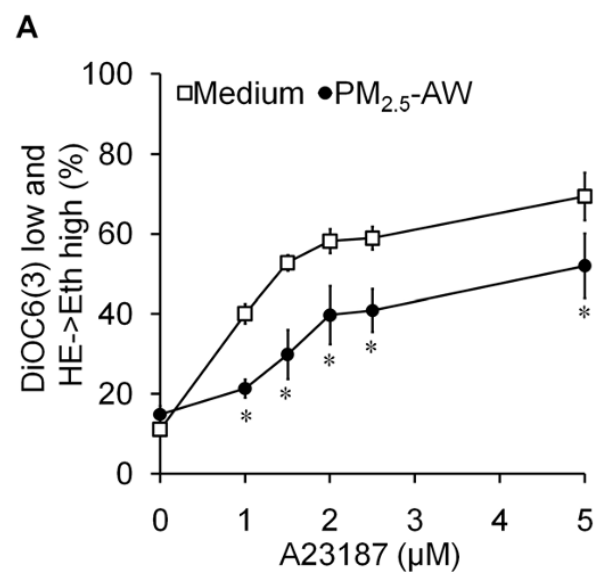

C

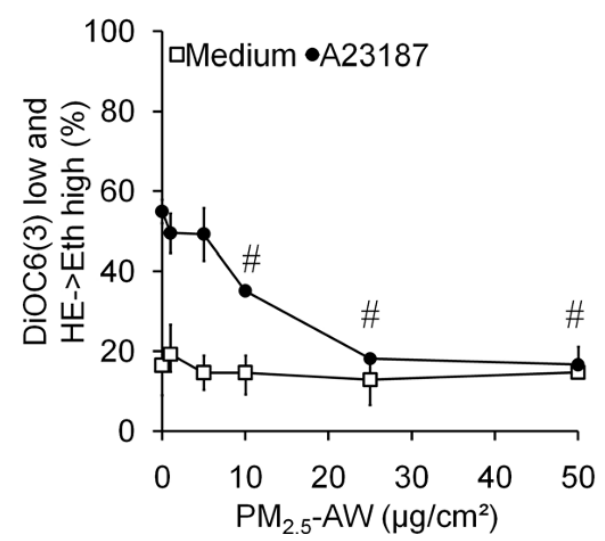

B

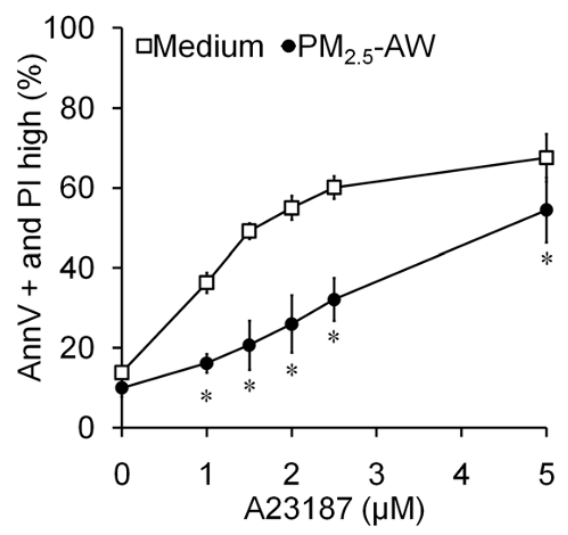

D

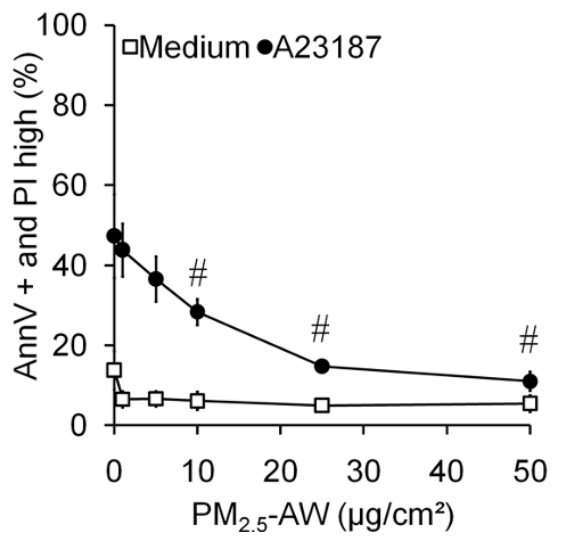

Figure 3 Dose-effect studies of the antiapoptotic effect of $\mathbf{P M}_{2.5}-\mathbf{A W}$. Apoptosis was quantified simultaneously by four parameters and expressed as percentage of $16 \mathrm{HBE}$ cells showing $\triangle \Psi \mathrm{m}$ drop (DiOC6(3) low) and ROS production (HE->Eth high) or PS exposure (Annexin $\mathrm{V}+$ ) and plasma membrane permeabilization (PI high). (A and B) After a 4 h pretreatment with $\mathrm{PM} 2.5^{-} \mathrm{AW}\left(10 \mu \mathrm{g} / \mathrm{cm}^{2}\right), 16 \mathrm{HBE}$ cells were exposed to the indicated concentrations of $A 23187$. Significance was calculated with respect to medium conditions (*, $p<0.001, \mathrm{n}=3$ ). $(\mathrm{C}$ and $\mathrm{D})$ Particle pretreatment was performed with different doses $\left(1-50 \mu \mathrm{g} / \mathrm{cm}^{2}\right) 4 \mathrm{~h}$ prior to induction of apoptosis by $3 \mu \mathrm{M}$ of $\mathrm{A} 23187$. Results are means \pm S.D $(n=3)$. Significance was calculated with respect to non-pretreated cells with particles $(\#, p<0.001)$.

soluble as well as organic compounds might be responsible for the antiapoptotic effect. To confirm this, we performed experiments with different heavy PAH (with at least 4 rings), such as Benzo[a]pyrene $(B(a) P)$, Dibenzo[a,h]anthracene (DB(a,h)A), Benzo[g,h,i]perylene $(\mathrm{B}(\mathrm{g}, \mathrm{h}, \mathrm{i}) \mathrm{P})$, Indeo[1,2,3-cd]pyrene (iP) and Benzo[b]fluoranthrene $(\mathrm{B}(\mathrm{b}) \mathrm{F})$. Except for $\mathrm{B}(\mathrm{b}) \mathrm{F}$, all the other $\mathrm{PAH}$ reduced the amount of apoptosis induced by A23187, similar to that of $\mathrm{PM}_{2.5}$ pretreatment and $\mathrm{B}(\mathrm{a}) \mathrm{P}$ seems to be the most efficient (Figure $6 \mathrm{~B}$ and $6 \mathrm{C}$ ). Note that the particle-coupled PAH are bioavailable in our system since CYP1A1 mRNA and its enzymatic activity were increased (data not shown). Moreover, when different light PAH (3-rings) found on particles were tested, the antiapoptotic effect was not found (Additional file 1 Figure S1). We also took into consideration the effect of biological compounds adsorbed onto particles, such as endotoxines, by using a specific bacteria LPS neutralizing protein rENP. This did not diminish the protector effect of $\mathrm{PM}_{2.5}$ from apoptosis induced by A23187 and STS (Additional file 1 Figure S2) indicating that endotoxins are not involved in the process. Altogether, our data strongly suggest that water-soluble and heavy $\mathrm{PAH}$ components contribute to the antiapoptotic effect of Parisian $\mathrm{PM}_{2.5}$ observed in human bronchial epithelial cells.

\section{The antiapoptotic mechanism is mediated by the aryl hydrocarbon receptor}

To delineate the molecular mechanism of the antiapoptotic effect of $\mathrm{PM}_{2.5}$ efficient at the mitochondrial checkpoint, we focused on the aryl hydrocarbon receptor (AhR) activated after cell exposure to organic compounds such as PAH. Indeed, AhR is a ligand-induced transcription factor which relocates to the nucleus and induces the expression of numerous target genes. Thus, we investigated the possible implication of AhR in our process. To test this we first either activated or inhibited 


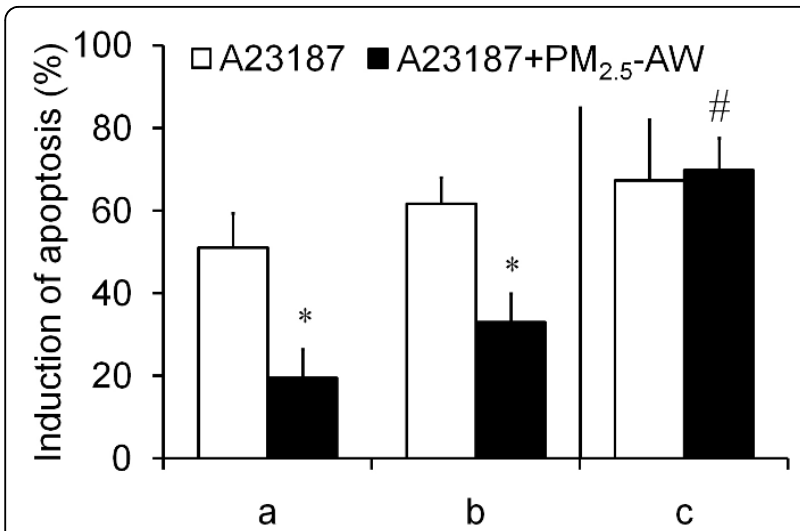

Figure 4 Study of direct adsorption of A23187 onto particles. (a) $16 \mathrm{HBE}$ cells were exposed $4 \mathrm{~h}$ to $10 \mu \mathrm{g} / \mathrm{cm}^{2} \mathrm{PM}_{2.5}$-AW prior to addition of $3 \mu \mathrm{M}$ A23187 during 20 supplementary hours. (b) To avoid possible adsorption, $\mathrm{PM}_{2.5}$-AW were removed and cells were washed five times with PBS before drug treatment. (c) Particles and A23187 were co-incubated $4 \mathrm{~h}$ into a coated 24 wells-plate without cells, and then supernatant was used to trigger apoptosis for $20 \mathrm{~h}$ supplementary. $\Delta \Psi \mathrm{m}$ dissipation was measured by flow cytometry and results are expressed as percentage of apoptosis induction as described in Materials and Methods section. Results are means $\pm S$. $D(n=3)$. Significance was calculated for $P_{2.5}-A W+A 23187$ versus

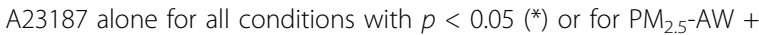
A23187 treatment with respect to $\mathrm{a}$, b or $\mathrm{c}$ condition (\#, $p<0.05$ ).

AhR, using an agonist (beta-naphtoflavone, beta-NF) or an antagonist (alpha-naphtoflavone, alpha-NF). Figure 7A shows that beta-NF $(20 \mu \mathrm{g} / \mathrm{ml})$ used prior to A23178 significantly reduced the amount of apoptotic cells (31\% reduction of DiOC6(3) low), and further improved the protection conferred by $\mathrm{PM}_{2.5}$ exposure (54\% vs. $37 \%$ reduction of DioC6(3) low). Conversely, pretreatment with alpha-NF significantly reduced the protection provided by $\mathrm{PM}_{2.5}$ exposure (25\% vs. $37 \%$ reduction of DiOC6(3) low), although it did not noticeably modify the apoptotic effect of A23187. These findings are consistent with the involvement of AhR in the antiapoptotic effect of $\mathrm{PM}_{2.5}$ exposure.

Finally, we tested the effect of AhR silencing in the antiapoptotic effect observed after $\mathrm{PM}_{2.5}$-exposure. For this, we used validated fluorescent-siRNA (Alexa Fluor 647 ) in order to select the fluorescent positive cells by flow cytometry. After siRNA optimization (80\% transfected cells with $10 \mathrm{nM}$ siRNA after $48 \mathrm{~h}$, data not shown) and validation of AhR silencing by western blot (Figure 7B upper panel), $\mathrm{DiOC}(6) 3$ and PI assays were performed by flow cytometry on cells exposed or not to $\mathrm{PM}_{2.5}$ and/or A23187 for $24 \mathrm{~h}$ as before. Figure $7 \mathrm{~B}$ (lower graph) shows that AhR silencing significantly reduced the protection triggered by $\mathrm{PM}_{2.5}$ (18\% vs. $27 \%$ reduction of $\mathrm{DiOC}(6) 3$ low) alike the antagonist (alphaNF) did. Interestingly, both the AhR silencing and AhR antagonist partially reduced the $\mathrm{PM}_{2.5}$-protective effect

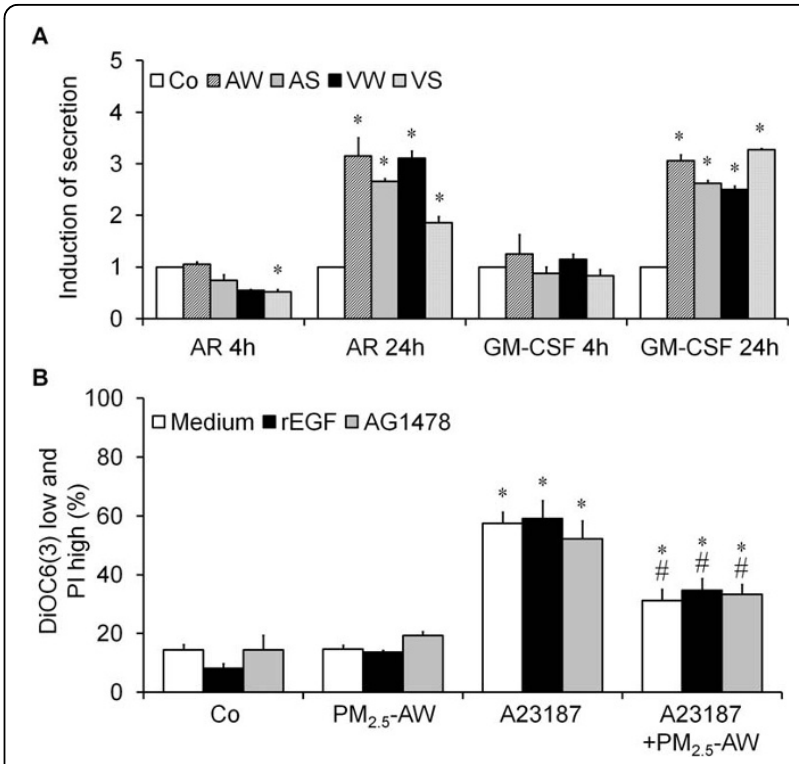

Figure 5 The antiapoptotic effect is not correlated with proinflammatory cytokines release after $\mathbf{P M}_{2.5}$ exposure. (A) Proinflammatory potential of different batches of $\mathrm{PM}_{2.5} 10 \mu \mathrm{g} / \mathrm{cm}^{2}$ (AW, AS, WW and VS) on 16HBE cells. After $4 \mathrm{~h}$ or $24 \mathrm{~h}$ particle exposure, Amphiregulin (AR) and granulocyte monocyte colonystimulating factor (GM-CSF) secretion were evaluated by ELISA. Data are represented as mean \pm SD of triplicates. ${ }^{*}$ indicates significance at $p<0.001$, treated vs. control. (B) Flow cytometric analysis was done as before in the presence or absence of $\mathrm{PM}_{2.5}-\mathrm{AW}$ pretreatement and/or apoptosis inducer A23187 (3 $\mu \mathrm{M})$ ). The implication of the EGFR was evaluated using the recombinant EGF ligand (rEGF $150 \mathrm{ng} / \mathrm{ml}$ ) or the inhibitor AG1478 (1 $\mu \mathrm{M})$ ). Data are represented as mean \pm SD of three independent results ( ${ }^{*}$ treated vs. control $p<0.05$; \# vs. A23187 alone, $p<0.05$ )

with almost the same extent (10\%). The increase in alpha-NF concentration $(20 \mu \mathrm{g} / \mathrm{ml}$, data not shown) or siRNA-AhR amount (25 nM, Additional file 1 Figure S3) did not completely abolish the protection suggesting that another pathway might be involved. Taken together, these results suggest that AhR partially contributes to the antiapoptotic effect of $\mathrm{PM}_{2.5}$ exposure.

\section{Discussion}

To our knowledge, this article is the first study presenting evidence that low concentrations of PM which are not cytotoxic, have an antiapoptotic effect on human bronchial epithelial cells. We report here the cellular effects of $\mathrm{PM}_{2.5}$ from two sites in Paris, sampled in winter and in summer. In order to remove the risk of cell type-specific events, our study was done in parallel on different human bronchial cell lines as well as on primary cells. We show that the four batches of $\mathrm{PM}_{2.5}$ are not cytotoxic on human bronchial cells, at a range of concentration from 1 to $50 \mu \mathrm{g} / \mathrm{cm}^{2}$. This is supported by data from flow cytometry, with the measurement of the main apoptotic hallmarks, as well as from electron 
A

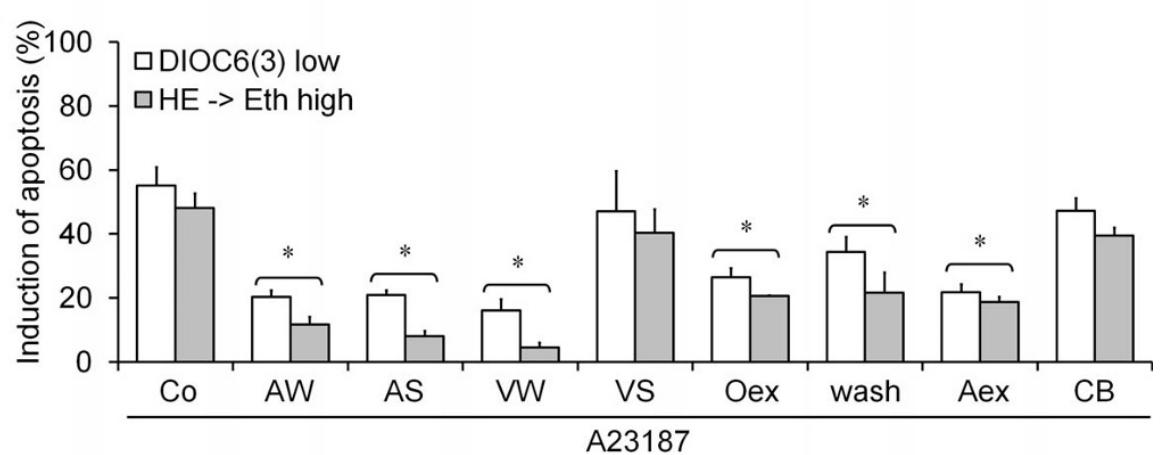

B

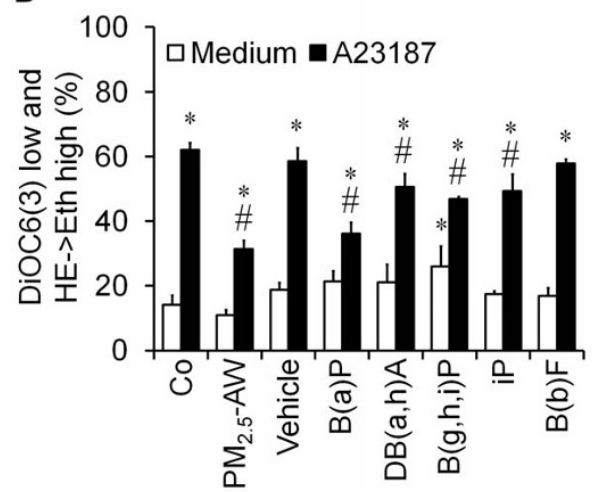

C

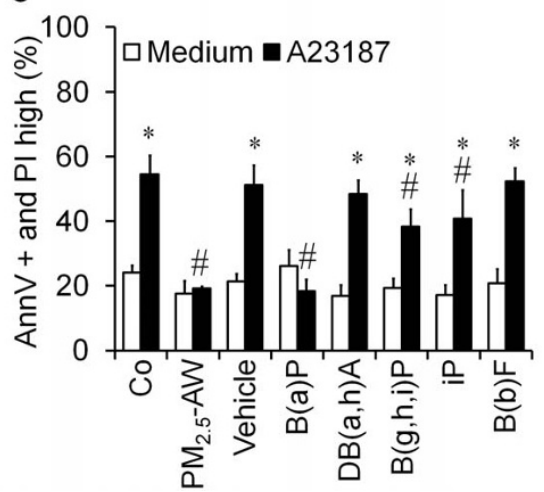

Figure 6 Role of the different components of $\mathbf{P M}_{\mathbf{2 . 5}}$ in the antiapoptotic effect. (A) 16HBE cells were treated $4 \mathrm{~h}$ with different batches of $\mathrm{PM}_{2.5} 10 \mathrm{\mu g} / \mathrm{cm}^{2}$ (AW, AS, WW and VS), the equivalent concentration of organic extracts (Oex, $4.27 \mathrm{mg} / \mathrm{ml}$ ), aqueous extracts (Aex), washed particles (wash, $10 \mu \mathrm{g} / \mathrm{cm}^{2}$ ) of $\mathrm{PM}_{2.5}$-AW and carbon black $\left(\mathrm{CB}, 10 \mu \mathrm{g} / \mathrm{cm}^{2}\right.$ ) before a $20 \mathrm{~h}$ exposure to A23187 (3 $\left.\mu \mathrm{M}\right)$. Apoptosis was assessed by flow cytometry and expressed as induction of apoptosis. Results are mean \pm SD $(n=3)$. ${ }^{*} p<0.001$ compared with A23187 alone. (B and C) Effect of heavy PAH on A23187-induced apoptosis. Treatments with $\mathrm{PM}_{2.5}-\mathrm{AW}\left(10 \mathrm{\mu g} / \mathrm{cm}^{2}\right)$, the vehicle (Cylohexane, 1\%), Benzo[a]pyrene (B(a)P, $270 \mathrm{nM})$, Dibenzo[a,h]anthracene (D,B(a,h)A, $35 \mathrm{nM})$, Benzo[g,h,i]perylene (B(g,h,i)P, $443 \mathrm{nM})$, Indeno[1,2,3-cd]pyrene (iP, $217 \mathrm{nM})$ and Benzo[b] fluoranthrene $(B(b) F, 333 n M)$, were performed $4 \mathrm{~h}$ prior to induction of apoptosis by $A 23187(3 \mu M)$. Results are mean $\pm S D(n=4)$. * vs. control, $p<0.001 ;$; vs. A23187, $p<0.05$.

microscopy data. Our results were obtained with a low concentration of $\mathrm{PM}_{2.5}$ unlike previous publications performed with higher doses (e.g. $100 \mu \mathrm{g} / \mathrm{cm}^{2}$, [18]). Indeed, the standard dose used here $\left(10 \mu \mathrm{g} / \mathrm{cm}^{2}\right)$ is a concentration which could mimic a five day exposure of $\mathrm{PM}_{2.5}$ in the tracheobronchial region, considering that $\mathrm{PM}_{2.5}$ mass deposition is $2.3 \mu \mathrm{g} / \mathrm{cm}^{2} / 24 \mathrm{~h}$ [11]. Our results are in agreement with a previous publication where BEAS-2B human bronchial cells were not susceptible to diesel exhaust particles-induced apoptosis [27] and here, we provided supplementary evidences of a non-toxicological activity of $\mathrm{PM}_{2.5}$ in NHBE primary culture. Moreover, in our studies and those of SanchezPerez et al. [28], the lack of induced-apoptosis triggered by PM at $10 \mu \mathrm{g} / \mathrm{cm}^{2}$ suggests that a "sub-lethal" concentration could have different impacts on cell fate than at high concentrations.

The originality of this work is that $\mathrm{PM}_{2.5}$ exposure confers a specific decrease in apoptosis induced by A23187, staurosporine and oligomycin as demonstrated in immortalized (16HBE), cancerous (NCI-H292, BEAS2B) as well as primary normal bronchial epithelial cells (NHBE). In order to characterize the molecular mechanism of the antiapoptotic activity of $\mathrm{PM}_{2.5}$ exposure, first we demonstrated that the reduction of apoptosis is observed prior to proinflammatory cytokines secretion which led us to rule out the involvement of the classical EGFR signaling pathway as well as the proinflammatory cytokines secretion by bronchial epithelial cells. However, $\mathrm{PM}_{2.5}$-antiapoptotic effect in addition to the welldocumented inflammatory response might explain the maintenance of a prolonged inflammation state in vivo induced after pollution exposure and might delay repair processes of injured tissues [29].

To further delineate the mechanism of the antiapoptotic activity, a strategy would be to identify the cellular targets which are in common between staurosporine, A23187 and oligomycin. On one hand, staurosporine and A23187 are known to regulate cellular calcium signaling pathways inducing an endoplasmic reticulum stress 


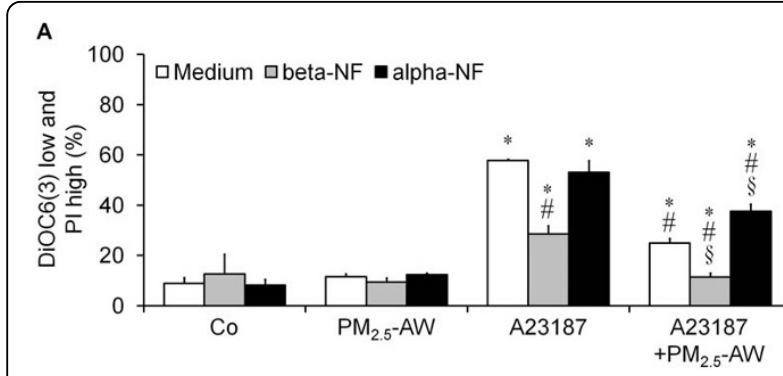

B

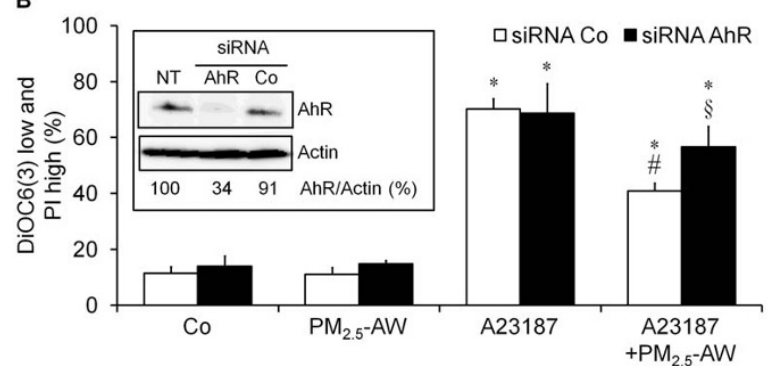

Figure 7 AhR pathway is involved in the antiapoptotic effect of Parisian $\mathbf{P M}_{2.5}$. (A) $16 \mathrm{HBE}$ epithelial cells were preincubated or not in the presence of the agonist beta-naphtoflavone (beta-NF, $20 \mu \mathrm{g} / \mathrm{ml}$ ) or the antagonist alpha-naphtoflavone (alpha-NF, $10 \mu \mathrm{g} / \mathrm{ml}$ ) one hour before the usual $\mathrm{PM}_{2.5}-\mathrm{AW}$ pretreatment and/or apoptosis inducer A23187 (3 $\mu \mathrm{M})$. Apoptosis was measured by flow cytometry as above. Results are mean \pm SD $(n=3) . p<0.001, *$ vs. Control, \# vs. A23187, $\S$ vs. A23187 $+\mathrm{PM}_{2.5}$. (B) Effect of AhR silencing. (Upper panel) $16 \mathrm{HBE}$ cells were incubated during $48 \mathrm{~h}$ with AhR siRNA (AhR, $10 \mathrm{nM}$ ), a control siRNA (Co, $10 \mathrm{nM})$ or non-transfected (NT), then total cell extract $(80 \mu \mathrm{g})$ were loaded onto gel and subjected to immunoblotting with anti-AhR and anti-Actin antibodies. Quantifications were performed as respect to Actin and illustrated as AhR/Actin ratio. (Lower Graph) $16 \mathrm{HBE}$ cells were incubated with siRNA for $48 \mathrm{~h}$ as above and then $4 \mathrm{~h}$ pretreated to $\mathrm{PM}_{2.5}$-AW before apoptosis induction with A23187 for $20 \mathrm{~h}$ supplementary. Results of flow cytometry (DiOC(6)3 low and IP high) are from transfected cells (Alexa Fluor 647 positive population) which were around $80 \%$ for all conditions, illustrated as mean $\pm \mathrm{SD}(\mathrm{n}=4) . p<0.001,{ }^{*}$ vs non-treated siRNA Co; $p<0.001$, \# vs. A23187 siRNA Co; $p<0.005$, § vs. A23187 + PM 2.5 siRNA Co.

which leads to cytoplasmic calcium uptake [24], mitochondrial $\mathrm{Ca}^{2+}$ overload [30] and finally $\Delta \Psi \mathrm{m}$ drop. Thus, $\mathrm{PM}_{2.5}$ exposure might counteract the $\mathrm{Ca}^{2+}$ uptake induced by these apoptotic inducers. However, this hypothesis is in discrepancy with the fact that the antiapoptotic effects of $\mathrm{PM}_{2.5}$ were not observed when using ionomycin, which is a well-known calcium ionophore, like A23187. Indeed, A23187 and ionomycin, which are both monocarboxylic ionophores, promote a selective increase of cytosolic $\mathrm{Ca}^{2+}$ [31]. But on the contrary to A23187 [24], a recent study showed that ionomycin did not allow the mitochondrial calcium overload in epimastigote cells of Trypanosoma cruzi [32]. The measurement of cytosolic and mitochondrial calcium uptakes in response to A23187 and ionomycin might allow us to understand why A23187-induced apoptosis is sensitive to $\mathrm{PM}$ while ionomycin is not. Moreover, caspases are the main effectors of apoptosis, but A23187, staurosporine and ionomycin can also activate $\mathrm{Ca}^{2+}$-specific proteases, such as calpains [33,34]. Indeed, our preliminary studies showed that calpains are activated after A23187 treatment of 16HBE and NCI-H292 cells (data not shown). As described for oligomycin, A23187, but not ionomycin, is a specific inhibitor of mitochondrial ATP synthase also known to catalyze the direct exchange of $\mathrm{Ca}^{2+} / 2 \mathrm{H}^{+}$in liver mitochondria [35] and to disrupt the mitochondrial transmembrane potential [36]. All these data suggest that ionomycin and A23187 might trigger the apoptotic process by slightly different mechanisms especially at the mitochondrial level. Thus, we hypothesize that $\mathrm{PM}_{2.5}$ could directly reduce apoptosis at the mitochondrial step by maintaining $\Delta \Psi \mathrm{m}$, or via the upregulation of antiapoptotic proteins such as Bcl-2 known to protect from A23187-induced apoptosis [24,37].

Humans are exposed to a mixture of compounds including organic and inorganic components adsorbed on PM. Evidences suggest that organic compounds such as the polycyclic aromatic hydrocarbons (PAH) can mimic the pro-oxidant [3] and apoptotic effect of PM [38]. Here, we investigated the role of different organic compounds (PAH, Oex), particles devoid of hydrosoluble components, (wash, $\mathrm{CB}$ ) and aqueous extracts (Aex) of $\mathrm{PM}_{2.5}$ with respect to cell death. We found that the organic extracts and several heavy $\mathrm{PAH}, \mathrm{B}(\mathrm{a}) \mathrm{P}$ in particular, could reproduce the antiapoptotic activity. Moreover, the water-soluble fraction also contributes to the reduction of apoptosis while carbon black, light PAH and endotoxins have no effect. In our study, $\mathrm{B}(\mathrm{a}) \mathrm{P}$ is the compound that protects the most efficiently from apoptosis induced by A23187. This points out a possible link between $\mathrm{PM}_{2.5}$-exposure and the antiapoptotic effect observed herein, as also suggested by Hung et al. [39]. The harmful health impacts of PAH are well-known, like the promotion of cancers. B(a)P-diones, which are photomodified by the sunlight, were also found in air particulate matter. In agreement with our results, a recent work demonstrated that sunlight-exposed $\mathrm{B}(\mathrm{a}) \mathrm{P}$ inhibits apoptosis induced by cell detachment [40]. B(a) $\mathrm{P}$ is metabolized by cells, transformed into a reactive intermediate (anti-7,8-dihydrodiol-9,10-epoxy-benzo[a] pyrene, BPDE) that causes DNA damage and mutations in tumor suppressor genes, such as p53 [41]. This toxic metabolite BPDE is also capable to suppress apoptosis of mammary epithelial cells [42].

The main cellular target of PAH adsorbed on PM is the aryl hydrocarbon receptor (AhR), thus we addressed the question of AhR involvement in the antiapoptotic effect after $\mathrm{PM}_{2.5}$ exposure. We showed here that the activation of $\mathrm{AhR}$ by the agonist beta-naphtoflavone improves the antiapoptotic effect. On the contrary, the inhibition of AhR (using a specific inhibitor or RNA 
silencing) diminished the antiapoptotic effect suggesting that AhR is involved in this process. An additional argument is brought by the absence of antiapoptotic activity when we tested light $\mathrm{PAH}$, which were previously shown to poorly promote AhR activation [43]. AhR is a cytoplasmic ligand-dependent transcription factor which translocates to the nucleus in order to bind specific Xenobiotic Responsive Elements in the promoter of its target genes, leading to the activation of phase I and II metabolizing enzymes and thus contributing to detoxification [44]. But in the absence of ligand, many data suggest other roles than detoxification [45] and recent evidences suggest that AhR inactivation could modify the expression of numerous genes, including those involved in cell cycle regulation [46]. In accordance with our results, other publications suggest an antiapoptotic activity of AhR by a direct interaction with E2F1 leading to the reduction of E2F1-mediated pro-apoptotic genes expression [47]. This is consistent with the idea that the AhR might modulate cell death at the mitochondrial checkpoint, for instance by upregulating the expression of antiapoptotic $b c l-2, b c l-x L, m c l-1$ or agr2 genes $[48,49]$ or by repressing the pro-apoptotic apaf-1 [47]. Moreover, AhR might indirectly regulate apoptosis through the MMP step by increasing the expression of the anti-apototic protein VDAC2 [50] which is known to participate to the permeability transition pore (PTP) and which also bind to and inhibit the apoptotic protein Bak [51]. In the light of our observations, it will be interesting to find out the genes encoding mitochondrial regulators which are modulated by $\mathrm{AhR}$ and involved in the protection observed after $\mathrm{PM}_{2.5}$-exposure or $\mathrm{B}(\mathrm{a}) \mathrm{P}$ treatment. It is also important to point out that both A23187 and STS could induce apoptosis via a $\mathrm{Ca}^{2+}$ -dependent pathway through mitochondrial PTP opening and that VDAC plays a crucial role in the transport of $\mathrm{Ca}^{2+}$ into this organelle [52].

\section{Conclusion}

In summary, Parisian $\mathrm{PM}_{2.5}$ are not cytotoxic in four cellular models of bronchial epithelial cells. However, $\mathrm{PM}_{2.5}$ exposure rapidly triggers an antiapoptotic effect at the mitochondrial level, which seems to be linked to the water-soluble and some PAH components adsorbed on particles. Finally, the AhR pathway partially contributes to the antiapoptotic effect of fine particles. Altogether, our results allow us to propose the hypothetic model in which desorbed PAH may activate the AhR leading to the regulation of genes involved in the mitochondrial checkpoint of apoptosis (Figure 8). In parallel, the water-soluble fraction seems to have similar effect on mitochondria by regulating unknown pathways. Our results are the first evidence of a missing link in the connection between adverse health effects of fine

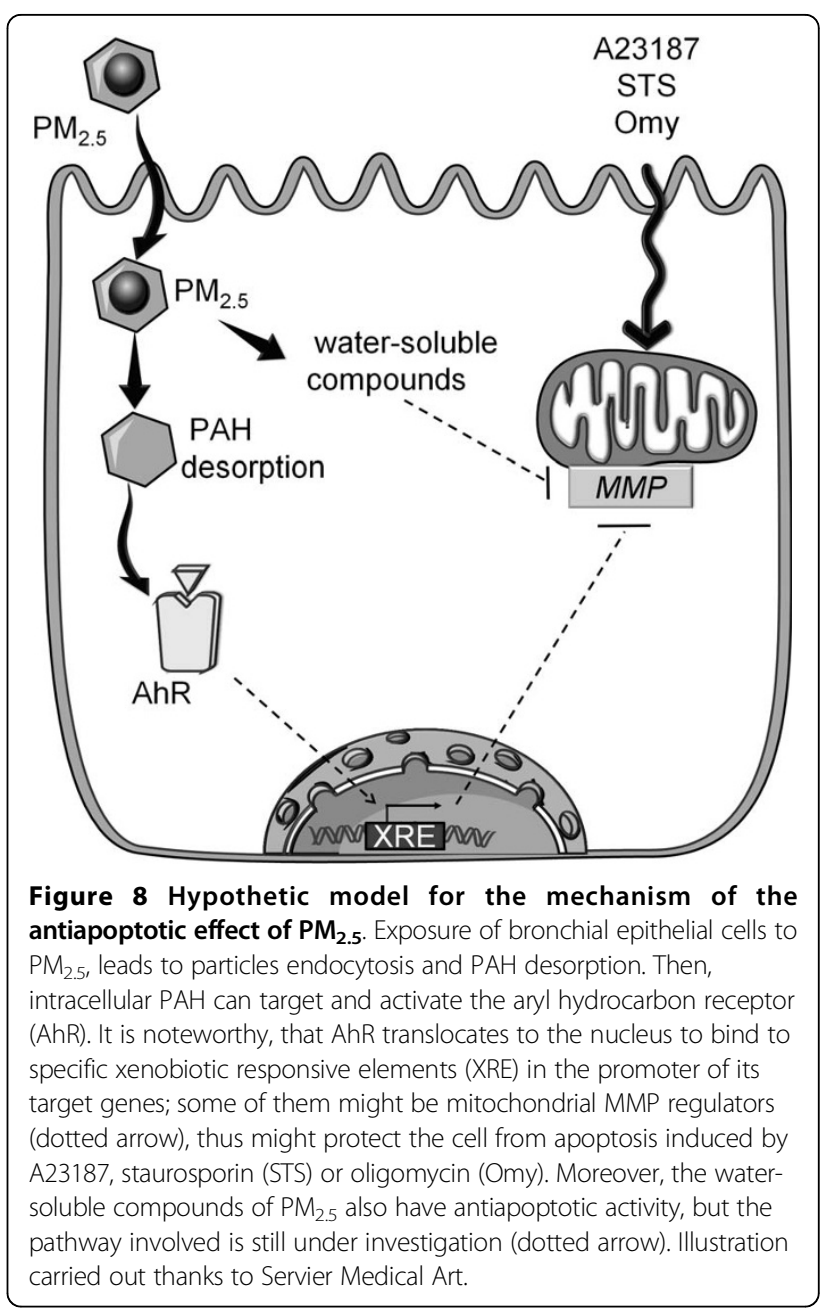

particles and exacerbation of cancerous pathologies, via the cell death impediment in their presence. Furthermore, the antiapoptotic effect of $\mathrm{PM}_{2.5}$ associated with the well-documented inflammatory response might also explain the maintenance of a prolonged inflammation state in vivo induced after pollution exposure.

\section{Materials and methods}

\section{Particles collection}

Urban atmospheric $\mathrm{PM}_{2.5}$ were collected during winter or summer 2003 at two locations in Paris: an urban background station at Vitry-sur-Seine (VW: Vitry winter and VS: Vitry summer), a suburb of Paris; and a curbside station at Porte d'Auteuil bordering the highway ring road of Paris (AW: Auteuil winter and AS: Auteuil summer). Particles were recovered on $150 \mathrm{~mm}$ diameter nitrocellulose filters (HAWP, Millipore, Saint-Quentin-en-Yvelines, France) with a high volume sampler machine (DA-80 Digitel, Switzerland, flowrate: $\left.30 \mathrm{~m}^{3} / \mathrm{h},[6]\right)$. Their PAH and metal content have been previously described [2]. $\mathrm{PM}_{2.5}$-AW organic extracts (Oex) were obtained after 
extraction by dichloromethane, then dried and redissolved in dimethyl sulfoxide (DMSO, Sigma). Oex were used at the concentration found on particles according to the soluble organic fraction (SOF) determined for $\mathrm{PM}_{2.5}$-AW particle sample (10\%). The aqueous extract of $\mathrm{PM}_{2.5}-\mathrm{AW}$ (Aex) containing hydrosoluble components was obtained after the washing of the particle suspension and two centrifugations at $10,000 \mathrm{~g}$, followed by filtration of the supernatant through a $0.22 \mu \mathrm{m}$ Durapore ${ }^{\bullet}$ filter (polyvinylidine difluoride) (Millex ${ }^{\oplus}$ GV, Carrigtohill, Cork, Ireland). Cells were exposed to a volume of aqueous extract equivalent to the volume of particle suspension used. Particles collected after the two centrifugations constitute the washed $\mathrm{PM}_{2.5^{-}}$ AW (wash) devoid of hydrosoluble components. Carbon black particles (CB, Fr101, $95 \mathrm{~nm}, 20 \mathrm{~m}^{2} / \mathrm{g}$ ) were purchased from Degussa (Frankfurt, Germany). All particles were stored in DMEM medium and used at standard dose $10 \mu \mathrm{g} / \mathrm{cm}^{2}(40 \mu \mathrm{g} / \mathrm{ml})$. For treatment, after thawing, particles were sonicated three times for $20 \mathrm{~s}$ at $70 \mathrm{~W}$ (Vibracell, Bioblock Scientific, Illkrich, France) and added directly onto the cells. Purified PAH, B(a)P, DB(a,h)A, B(g,h,i)P, iP, $\mathrm{B}(\mathrm{b}) \mathrm{F}, \mathrm{PA}, \mathrm{FA}$ and vehicle cyclohexane were purchased from Sigma.

\section{Cell culture conditions}

Human bronchial epithelial cells $16 \mathrm{HBE} 140$ - kindly provided by Dr. D.C. Gruenert (Colchester, VT, USA [53], were cultured in DMEM/F12 medium (Invitrogen) supplemented with $2 \mathrm{mM}$ GlutaMAX ${ }^{\mathrm{Tm}}$-I, $100 \mathrm{U} / \mathrm{ml}$ penicillin, $100 \mu \mathrm{g} / \mathrm{ml}$ streptomycin, $1.25 \mu \mathrm{g} / \mathrm{ml}$ fungizone and $2 \%$ UltroserG (UG, BioSepra, France). Cells were grown to subconfluence on bovine collagen (Purecol Natucan, $0.5 \mathrm{mg} / \mathrm{cm}^{2}$ ) and human fibronectin coating (Sigma, 4 $\left.\mu \mathrm{g} / \mathrm{cm}^{2}\right)$. Prior to particle treatment, UG was removed. BEAS-2B human bronchial epithelial cells (provided by Dr. J. Boczkowski, Faculté de Médecine Xavier Bichat, Université Paris 7, France) were cultured in LHC-9 medium containing retinoic acid (33 $\mathrm{nM})$. The human lung mucoepidermoid carcinoma cells (NCI-H292) were purchased from the American Type Culture Collection (Rockville, MD) and cultured in RPMI-1640 medium (Invitrogen) supplemented with $1 \%$ GlutaMAX $^{\mathrm{TM}}-\mathrm{I}$ and $10 \%$ fetal calf serum. Primary cultures of normal human bronchial epithelial (NHBE) cells were obtained from Lonza and cultured for in Clonetics ${ }^{\circledR}$ BEGM medium (Cambrex, Walkersville, MD, USA) supplemented with EGF $25 \mathrm{ng} / \mathrm{ml}$. During treatment NHBE cells were grown in DMEM/F12 without growth factors.

\section{Chemicals and apoptosis measurement}

Cells were exposed $4 \mathrm{~h}$ to $\mathrm{PM}_{2.5}\left(1-50 \mu \mathrm{g} / \mathrm{cm}^{2}\right)$ prior to addition of apoptotic inducers for additional 20 hours: rotenone (Rot, $5 \mu \mathrm{M}$ ), antimycin (AMA, $25 \mu \mathrm{g} / \mathrm{ml}$ ), oligomycine (Omy, $5 \mu \mathrm{M}$ ), ionomycin (Iono, $0.5 \mu \mathrm{M}$ ), A23187
(3 $\mu \mathrm{M})$, staurosporine (STS, $1 \mu \mathrm{M}$ ) and hydrogen peroxide $\left(\mathrm{H}_{2} \mathrm{O}_{2}, 500 \mu \mathrm{M}\right)$. All drugs were purchased from Sigma. Apoptotic parameters were quantified by flow cytometry performed on CyAn ADP LX (Dako Cytomentation funded by the Ligue Nationale contre le Cancer R03/ 75-79) using 3, 3 dihexyloxacarbocyanine iodide $\left(\mathrm{DiOC}_{6}\right.$ (3), $2 \mathrm{nM}$ ) for $\Delta \Psi \mathrm{m}$ quantification, $10 \mu \mathrm{g} / \mathrm{ml}$ propidium iodide (PI) for determination of plasma membrane permeabilization, $2 \mu \mathrm{M}$ hydroethidine (HE, Molecular Probes) for superoxide anion generation, and Annexin V conjugated with fluorescein isothiocyanate (FITC, Sigma) for the assessment of phosphatidylserine (PS) exposure [54]. Percentage of induction of apoptosis is calculated according to the following formula: $\%=100 \times(\%$ of apoptotic treated cells - \% of apoptotic control cells $) /(100-\%$ of apoptotic control cells). Recombinant EGF (rEGF) and EGFR inhibitor (AG1478) are from Sigma. The specific AhR antagonist alpha-naphthoflavone (alpha-NF, $10 \mu \mathrm{g} / \mathrm{ml}$, Sigma) or agonist beta-naphthoflavone (beta$\mathrm{NF}, 20 \mu \mathrm{g} / \mathrm{ml}$, Sigma) were used for $1 \mathrm{~h}$ prior to $\mathrm{PM}_{2.5}$ exposure and/or apoptosis induction.

\section{Electron Microscopy}

Cells were fixed $1 \mathrm{~h}$ by immersion at $4^{\circ} \mathrm{C}$ in $2.5 \%$ glutaraldehyde and $1 \%$ tannic acid in $0.1 \mathrm{M}$ sodium cacodylate buffer, washed, postfixed in $2 \%$ osmium tetroxide deshydrated before embedding in Epon. Electron microscopy was performed with a transmission electron microscope (model Philips TECNAI 12), at $80 \mathrm{kV}$ on ultrathin sections $(60 \mathrm{~nm})$.

\section{Amphiregulin and GM-CSF secretion}

Subconfluent $16 \mathrm{HBE}$ cells were exposed to $\mathrm{PM}_{2.5}$-AW for $4 \mathrm{~h}$ or $24 \mathrm{~h}$ and supernatants were recovered, centrifuged at $15,000 \times \mathrm{g}$ for $15 \mathrm{~min}$ at $4^{\circ} \mathrm{C}$ to pellet particles, and then frozen at $-80^{\circ} \mathrm{C}$ until further analysis. The concentrations of Amphiregulin (AR) and GM-CSF released were evaluated with an enzyme-linked immunosorbent assay kit (ELISA, R\&D Systems Europe; Abingdon, UK) according to the manufacturer's recommendations.

\section{AhR gene silencing}

$16 \mathrm{HBE}$ cells were simultaneously seeded at $2 \times 10^{4}$ cells $/ \mathrm{cm}^{2}$ either in T25 dishes (for Western Blot) or in a P24 well plate (for flow cytometry) and incubated under normal cell culture conditions overnight. Then, $10 \mathrm{nM}$ of AhR siRNA (Hs_AHR_6 AlexaFluor-647, Ref SI03043971, Qiagen) or control non-silencing siRNA (AllStars Neg AlexaFluor-647, Ref 1027287, Qiagen) and HiPerFect Transfection Reagent (Qiagen) were mixed separately in medium and the formed-complexes were then added drop-wise onto the cells, according to the manufacturer's recommendations. At $48 \mathrm{~h}$ after transfection, the cells were subjected to our usual protocol: $4 \mathrm{~h}$ 
$\mathrm{PM}_{2.5}$ pretreatement and/or A23187 (3 $\left.\mu \mathrm{M}\right)$ for additional $20 \mathrm{~h}$.

\section{Western Blots}

Western Blots were performed according to the method previously described [55] and the primary antibodies used were: mouse-monoclonal anti-AhR (WH0000196M2, Sigma) and anti-Actin (A5441, Sigma). The secondary antibodies (peroxidase-conjugated) were anti-mouse immunoglobulin (A9044, Sigma). Immunoreactive bands were detected by chemiluminescence using a Chemiluminescent Sensitive HRP Substrate (BioFX Laboratories) using a FujiFilm LAS 4000 camera system.

\section{Statistical analysis}

All results are presented as the mean $+/$ - standard deviation of three independent experiments. Data were analyzed using one-way ANOVA analysis of variance. The Dunnett's test was performed for all multiple comparisons versus control group. Moreover, the StudentNewman-Keuls test was used for all pairwise comparisons of mean responses among the different treatment groups (SigmaStat). Differences between groups were considered significant if the $p$ value was less than 0.05 .

\section{Funding information}

This work was supported by Agence Nationale de la Recherche [0599-5 SET 024-01], Centre National de la Recherche Scientifique (CNRS), Université Paris Diderot-Paris 7 (Bourse de Master, Melanie Leroux), Région Ile de France (Allocation post-doctorale, Ioana Ferecatu [F-08-1261/R]), ADEME-Primequal [0462C0056], CAMPLP (Caisse d'Assurance Maladie des Professions Liberales de Province, Paris, France), Renault (DIMAT, for the supply and chemical analysis of $\mathrm{PM}_{2.5}$ and PM organic extracts) and Legs Poix.

\section{Additional material}

Additional file 1: Figure S1: The antiapoptotic effect of PM2.5 is not related to light three-rings PAH. Figure S2: The antiapoptotic effect of $\mathrm{PM}_{2.5}$ is not related to the adsorbed endotoxins. Figure $\mathbf{S 3}$ : Higher amounts of AhR siRNA do not completely abolish the antiapoptotic effect of $\mathrm{PM}_{2.5}$ exposure.

\section{Abbreviations}

A23187: calcium ionophore (calcimycin); Aex: aqueous extracts; AhR: aryl hydrocarbon receptor; alpha-NF: alpha-naphtoflavone; AMA: antimicyn A; AR: Amphiregulin; B(a)P: benzo[a]pyrene; B(b)F: benzo[b]fluoranthrene; B(g,h,i)P: benzo[g,h,i]perylene; beta-NF: beta-naphtoflavone; COPD: chronic obstructive pulmonary diseases; DB(a,h)A: dibenzo[a,h]anthracene; DEP: Diesel exhaust particles; $\mathrm{DiOC}_{6}(3): 3,3$ dihexyloxacarbocyanine iodide; EGF: epidermal growth factor; FA: fluoranthene; FITC: fluorescein isothiocyanate; GM-CSF: granulocyte monocyte colony-stimulating factor; $\mathrm{H}_{2} \mathrm{O}_{2}$ : hydrogen peroxide; HE: hydroethidine; Iono: ionomycin; iP: indeo[1,2,3-cd]pyrene; LPS: lipopolysaccharide; MMP: mitochondrial membrane permeabilization; Oex: organic extracts; Omy: oligomycin; PA: phenanthren; PAH: polycyclic aromatic hydrocarbons; PI: propidium iodide; PM: particulate matter; $\mathrm{PM}_{2.5}$ AS: Auteuil summer; $\mathrm{PM}_{2.5}-\mathrm{AW}$ : Auteuil winter; $\mathrm{PM}_{2.5}$-VS: Vitry summer; $\mathrm{PM}_{2.5}$ W: Vitry winter; PS: phosphatidylserine; ROS: reactive oxygen species; Rot: rotenone; siRNA: small interfering RNA; STS: staurosporine; wash: washed particles; $\triangle \Psi \mathrm{m}$ : mitochondrial transmembrane potential.

\section{Acknowledgements}

We thank Annie Jaeger and Marie Claude Gendron for their technical assistance and Emeline Assémat for advice on NHBE culture. We thank Mabel Jouve-San Roman from the Jacques Monod Institute (Paris, France) for help in electron microscopy. We also thank Sonja Boland, Martine Aggerbeck and Christophe Lemaire for their critical reading of the manuscript.

\section{Author details}

${ }^{1}$ Université Paris Diderot-Paris 7. Unit of Functional and Adaptive Biology (BFA) CNRS EAC 4413, Laboratory of Molecular and Cellular Responses to Xenobiotics, Bâtiment Buffon, case courrier 7073, 5 rue Thomas Mann, 75013 Paris, France. ${ }^{2}$ Université Paris Diderot-Paris 7. Flow Cytometry Unit, Jacques Monod Institute, 75013 Paris, France.

\section{Authors' contributions}

IF and KA designed the research, analyzed the data and drafted the paper. $I F, M C B, C B, M L, N B$ and $K A$ performed the experiments. $A B$ and $F M$ contributed to the interpretation of the data and helped improving the manuscript. All authors read and approved the final manuscript.

\section{Competing interests}

The authors declare that they have no competing interests.

Received: 30 April 2010 Accepted: 21 July 2010 Published: 21 July 2010

\section{References}

1. Boland S, Baeza-Squiban A, Marano F: Toxicité respiratoire des particules Diesel: les mécanismes cellulaires et moléculaires. Médecine Sciences 2001, 17:596-603.

2. Baulig A, Poirault JJ, Ausset P, Schins R, Shi T, Baralle D, Dorlhene P, Meyer M, Lefevre R, Baeza-Squiban A, Marano F: Physicochemical characteristics and biological activities of seasonal atmospheric particulate matter sampling in two locations of Paris. Environ Sci Technol 2004, 38:5985-5992.

3. Baulig A, Garlatti M, Bonvallot V, Marchand A, Barouki R, Marano F, BaezaSquiban A: Involvement of reactive oxygen species in the metabolic pathways triggered by diesel exhaust particles in human airway epithelial cells. Am J Physiol Lung Cell Mol Physiol 2003, 285:L671-679.

4. Boland S, Baeza-Squiban A, Fournier T, Houcine O, Gendron MC, Chevrier M, Jouvenot G, Coste A, Aubier M, Marano F: Diesel exhaust particles are taken up by human airway epithelial cells in vitro and alter cytokine production. Am J Physiol 1999, 276:L604-613.

5. Calcabrini A, Meschini S, Marra M, Falzano L, Colone M, De Berardis B, Paoletti L, Arancia G, Fiorentini C: Fine environmental particulate engenders alterations in human lung epithelial A549 cells. Environ Res 2004, 95:82-91.

6. Baulig A, Blanchet S, Rumelhard M, Lacroix G, Marano F, Baeza-Squiban A: Fine urban atmospheric particulate matter modulates inflammatory gene and protein expression in human bronchial epithelial cells. Front Biosci 2007, 12:771-782.

7. Hetland RB, Cassee FR, Lag M, Refsnes M, Dybing E, Schwarze PE: Cytokine release from alveolar macrophages exposed to ambient particulate matter: heterogeneity in relation to size, city and season. Part Fibre Toxicol 2005, 2:4.

8. Gualtieri M, Mantecca P, Cetta F, Camatini M: Organic compounds in tire particle induce reactive oxygen species and heat-shock proteins in the human alveolar cell line A549. Environ Int 2008, 34:437-442.

9. Rumelhard M, Ramgolam K, Hamel R, Marano F, Baeza-Squiban A: Expression and role of EGFR ligands induced in airway cells by PM2.5 and its components. Eur Respir J 2007, 30:1064-1073.

10. Pope CAr, Burnett RT, Thun MJ, Calle EE, Krewski D, Ito K, Thurston GD: Lung cancer, cardiopulmonary mortality, and long-term exposure to fine particulate air pollution. JAMA 2002, 287:1132-1141. 
11. Li N, Hao M, Phalen RF, Hinds WC, Nel AE: Particulate air pollutants and asthma. A paradigm for the role of oxidative stress in PM-induced adverse health effects. Clin Immunol 2003, 109:250-265.

12. Hertz-Picciotto I, Baker RJ, Yap PS, Dostal M, Joad JP, Lipsett M, Greenfield T, Herr CE, Benes I, Shumway RH, et al: Early childhood lower respiratory illness and air pollution. Environ Health Perspect 2007, 115:1510-1518.

13. Sint T, Donohue JF, Ghio AJ: Ambient air pollution particles and the acute exacerbation of chronic obstructive pulmonary disease. Inhal Toxicol 2008, 20:25-29.

14. Norman R, Cairncross E, Witi J, Bradshaw D: Estimating the burden of disease attributable to urban outdoor air pollution in South Africa in 2000. S Afr Med J 2007, 97:782-790.

15. Churg A, Brauer M, del Carmen Avila-Casado M, Fortoul TI, Wright JL: Chronic exposure to high levels of particulate air pollution and small airway remodeling. Environ Health Perspect 2003, 111:714-718.

16. Tagaya E, Tamaoki J: Mechanisms of airway remodeling in asthma. Allergol Int 2007, 56:331-340.

17. Kroemer G, Galluzzi L, Vandenabeele P, Abrams J, Alnemri ES, Baehrecke EH, Blagosklonny MV, El-Deiry WS, Golstein P, Green DR, et al: Classification of cell death: recommendations of the Nomenclature Committee on Cell Death 2009. Cell Death Differ 2009, 16:3-11.

18. Zhang J, Ghio AJ, Chang W, Kamdar O, Rosen GD, Upadhyay D: Bim mediates mitochondria-regulated particulate matter-induced apoptosis in alveolar epithelial cells. FEBS Lett 2007, 581:4148-4152.

19. Dagher Z, Garcon G, Billet S, Gosset P, Ledoux F, Courcot D, Aboukais A, Shirali P: Activation of different pathways of apoptosis by air pollution particulate matter (PM2.5) in human epithelial lung cells (L132) in culture. Toxicology 2006, 225:12-24.

20. Agopyan N, Head J, Yu S, Simon SA: TRPV1 receptors mediate particulate matter-induced apoptosis. Am J Physiol Lung Cell Mol Physiol 2004, 286 L563-572.

21. Franco R, Sanchez-Olea R, Reyes-Reyes EM, Panayiotidis Ml: Environmental toxicity, oxidative stress and apoptosis: menage a trois. Mutat Res 2009, 674:3-22.

22. Pulido MD, Parrish AR: Metal-induced apoptosis: mechanisms. Mutat Res 2003, 533:227-241

23. Soukup JM, Becker S: Human alveolar macrophage responses to air pollution particulates are associated with insoluble components of coarse material, including particulate endotoxin. Toxicol Appl Pharmacol 2001, 171:20-26.

24. Deniaud A, Sharaf el dein O, Maillier E, Poncet D, Kroemer G, Lemaire C, Brenner C: Endoplasmic reticulum stress induces calcium-dependent permeability transition, mitochondrial outer membrane permeabilization and apoptosis. Oncogene 2008, 27:285-299.

25. Val S, Hussain S, Boland S, Hamel R, Baeza-Squiban A, Marano F: Carbon black and titanium dioxide nanoparticles induce pro-inflammatory responses in bronchial epithelial cells: Need for multiparametric evaluation due to adsorption artifacts. Inhal Toxicol 2009, 21:115-122.

26. Rumelhard M, Ramgolam K, Auger F, Dazy AC, Blanchet S, Marano F, BaezaSquiban A: Effects of PM2.5 components in the release of amphiregulin by human airway epithelial cells. Toxicol Lett 2007, 168:155-164.

27. Hiura TS, Kaszubowski MP, Li N, Nel AE: Chemicals in diesel exhaust particles generate reactive oxygen radicals and induce apoptosis in macrophages. J Immunol 1999, 163:5582-5591.

28. Sanchez-Perez Y, Chirino Yl, Osornio-Vargas AR, Morales-Barcenas R, Gutierrez-Ruiz C, Vazquez-Lopez I, Garcia-Cuellar CM: DNA damage response of A549 cells treated with particulate matter (PM10) of urban air pollutants. Cancer Lett 2009, 278:192-200.

29. Kuwano K: Involvement of epithelial cell apoptosis in interstitial lung diseases. Intern Med 2008, 47:345-353.

30. Hamahata K, Adachi S, Matsubara H, Okada M, Imai T, Watanabe K, Toyokuni SY, Ueno M, Wakabayashi S, Katanosaka Y, et al: Mitochondrial dysfunction is related to necrosis-like programmed cell death induced by A23187 in CEM cells. Eur J Pharmacol 2005, 516:187-196.

31. Liu C, Hermann TE: Characterization of ionomycin as a calcium ionophore. J Biol Chem 1978, 253:5892-5894.

32. Irigoin F, Inada NM, Fernandes MP, Piacenza L, Gadelha FR, Vercesi $A E$, Radi R: Mitochondrial calcium overload triggers complement-dependent superoxide-mediated programmed cell death in Trypanosoma cruzi. Biochem J 2009, 418:595-604.
33. Orrenius S, Zhivotovsky B, Nicotera P: Regulation of cell death: the calcium-apoptosis link. Nat Rev Mol Cell Biol 2003, 4:552-565.

34. Mattson MP, Chan SL: Calcium orchestrates apoptosis. Nat Cell Biol 2003, 5:1041-1043.

35. Brand MD: Electroneutral efflux of $\mathrm{Ca} 2+$ from liver mitochondria. Biochem J 1985, 225:413-419.

36. Reed PW, Lardy HA: A23187: a divalent cation ionophore. J Biol Chem 1972, 247:6970-6977.

37. Zhang QH, Sheng HP, Loh TT: bcl-2 protects HL-60 cells from apoptosis by stabilizing their intracellular calcium pools. Life Sci 2001, 68:2873-2883.

38. Xia T, Korge P, Weiss JN, Li N, Venkatesen Ml, Sioutas C, Nel A: Quinones and aromatic chemical compounds in particulate matter induce mitochondrial dysfunction: implications for ultrafine particle toxicity. Environ Health Perspect 2004, 112:1347-1358.

39. Hung HS, Wu WJ, Cheng YW, Wu TC, Chang KL, Lee H: Association of cooking oil fumes exposure with lung cancer: involvement of inhibitor of apoptosis proteins in cell survival and proliferation in vitro. Mutat Res 2007, 628:107-116.

40. Teranishi M, Toyooka T, Ohura T, Masuda S, Ibuki Y: Benzo[a]pyrene exposed to solar-simulated light inhibits apoptosis and augments carcinogenicity. Chem Biol Interact 2010.

41. Conney AH, Chang RL, Jerina DM, Wei SJ: Studies on the metabolism of benzo[a]pyrene and dose-dependent differences in the mutagenic profile of its ultimate carcinogenic metabolite. Drug Metab Rev 1994, 26:125-163.

42. Burdick AD, Ivnitski-Steele ID, Lauer FT, Burchiel SW: PYK2 mediates antiapoptotic AKT signaling in response to benzo[a]pyrene diol epoxide in mammary epithelial cells. Carcinogenesis 2006, 27:2331-2340.

43. Willett KL, Randerath K, Zhou GD, Safe SH: Inhibition of CYP1A1dependent activity by the polynuclear aromatic hydrocarbon (PAH) fluoranthene. Biochem Pharmacol 1998, 55:831-839.

44. Hankinson O: The aryl hydrocarbon receptor complex. Annu Rev Pharmacol Toxicol 1995, 35:307-340

45. Puga A, Ma C, Marlowe JL: The aryl hydrocarbon receptor cross-talks with multiple signal transduction pathways. Biochem Pharmacol 2009, 77:713-722.

46. Fan Y, Boivin GP, Knudsen ES, Nebert DW, Xia Y, Puga A: The aryl hydrocarbon receptor functions as a tumor suppressor of liver carcinogenesis. Cancer Res 2010, 70:212-220.

47. Marlowe JL, Fan Y, Chang X, Peng L, Knudsen ES, Xia Y, Puga A: The aryl hydrocarbon receptor binds to E2F1 and inhibits E2F1-induced apoptosis. Mol Biol Cell 2008, 19:3263-3271.

48. Vogel CF, Li W, Sciullo E, Newman J, Hammock B, Reader JR, Tuscano J, Matsumura F: Pathogenesis of aryl hydrocarbon receptor-mediated development of lymphoma is associated with increased cyclooxygenase-2 expression. Am J Pathol 2007, 171:1538-1548.

49. Ambolet-Camoit A, Bui LC, Pierre S, Chevallier A, Marchand A, Coumoul X, Garlatti M, Andreau K, Barouki R, Aggerbeck M: 2,3,7,8-Tetrachlorodibenzo$\mathrm{p}$-Dioxin counteracts the p53 response to a genotoxicant by upregulating expression of the metastasis marker AGR2 in the hepatocarcinoma cell line HepG2. Toxicol Sci 2010.

50. Sarioglu H, Brandner S, Haberger M, Jacobsen C, Lichtmannegger J, Wormke M, Andrae U: Analysis of 2,3,7,8-tetrachlorodibenzo-p-dioxininduced proteome changes in $5 \mathrm{~L}$ rat hepatoma cells reveals novel targets of dioxin action including the mitochondrial apoptosis regulator VDAC2. Mol Cell Proteomics 2008, 7:394-410.

51. Cheng EH, Sheiko TV, Fisher JK, Craigen WJ, Korsmeyer SJ: VDAC2 inhibits BAK activation and mitochondrial apoptosis. Science 2003, 301:513-517.

52. Bathori G, Csordas G, Garcia-Perez C, Davies E, Hajnoczky G: Ca2 +-dependent control of the permeability properties of the mitochondrial outer membrane and voltage-dependent anion-selective channel (VDAC). J Biol Chem 2006, 281:17347-17358.

53. Cozens AL, Yezzi MJ, Kunzelmann K, Ohrui T, Chin L, Eng K, Finkbeiner WE, Widdicombe $J H$, Gruenert DC: CFTR expression and chloride secretion in polarized immortal human bronchial epithelial cells. Am J Respir Cell Mol Biol 1994, 10:38-47.

54. Andreau K, Castedo M, Perfettini IL, Roumier T, Pichart E, Souquere $\mathrm{S}$, Vivet S, Larochette N, Kroemer G: Preapoptotic chromatin condensation upstream of the mitochondrial checkpoint. J Biol Chem 2004, 279:55937-55945. 
55. Ferecatu I, Bergeaud M, Rodriguez-Enfedaque A, Le Floch N, Oliver L, Rincheval V, Renaud F, Vallette FM, Mignotte B, Vayssiere JL: Mitochondrial localization of the low level p53 protein in proliferative cells. Biochem Biophys Res Commun 2009, 387:772-777.

doi:10.1186/1743-8977-7-18

Cite this article as: Ferecatu et al:: Polycyclic aromatic hydrocarbon components contribute to the mitochondria-antiapoptotic effect of fine particulate matter on human bronchial epithelial cells via the aryl hydrocarbon receptor. Particle and Fibre Toxicology 2010 7:18.

Submit your next manuscript to BioMed Central and take full advantage of:

- Convenient online submission

- Thorough peer review

- No space constraints or color figure charges

- Immediate publication on acceptance

- Inclusion in PubMed, CAS, Scopus and Google Scholar

- Research which is freely available for redistribution

Submit your manuscript at www.biomedcentral.com/submit
C Biomed Central 